\title{
Incidence of respiratory tract infections and antibiotic use in primary health care
}

MAŁGORZATA PIETRZYKOWSKA ${ }^{\mathrm{A}-\mathrm{F}}$, KATARZYNA NOWICKA-SAUER ${ }^{\mathrm{A}, \mathrm{D}, \mathrm{E}}$, PIOTR GUTKNECHTF, JANUSZ SIEBERT ${ }^{\mathrm{A}, \mathrm{D}, \mathrm{E}}$

Department of Family Medicine, Medical University of Gdansk

A - Study Design, B - Data Collection, C - Statistical Analysis, D - Data Interpretation, E - Manuscript Preparation, $\mathbf{F}$ - Literature Search, $\mathbf{G}$ - Funds Collection

Summary Background. Respiratory tract infections are of viral etiology in around $70 \%$ of cases. The most popular treatment method is the empirical approach based on a medical interview and a physical examination, using the doctor's personal experience. Contrary to recommendations, antibiotic overuse is prevalent. The excessive use of antibiotics is a major factor contributing to the growing antibiotic resistance of bacteria, leading to epidemiological risk.

Objectives. This study aimed to establish the incidence of respiratory tract infection and analyze the structure of antibiotic prescription in primary health care (PHC).

Material and methods. Retrospective medical records of 500 adult patients treated for respiratory tract infection in the first quarter of 2014, in a PHC facility in Pomeranian province were examined. The age median was 51 (range: 18 to 100). The study was focused on the incidence of disease diagnosis as classified by ICD-10 and on the treatment method used with respect to various antibiotic groups.

Results. Acute upper respiratory tract infection with multiple or unspecified sites was diagnosed in $286(57.2 \%)$ patients. Acute bronchitis was the second most common diagnosis $(10.2 \%)$. Two patients were diagnosed with influenza $(0.4 \%)$. As many as $67.2 \%$ of all patients were treated with antibiotics. Semisynthetic penicillin - such as amoxicillin or amoxicillin with clavulanic acid $-(46.43 \%$ in total) and macrolides (36.31\%) were the most frequently prescribed.

Conclusions. 1. Acute upper respiratory tract infection with multiple or unspecified sites was diagnosed most frequently. 2. Despite increasing awareness of the risks associated with the excessive use of antibiotics, antimicrobials were often prescribed. Semisynthetic penicillins and macrolides were used most often. 3. Implementation of uniform national standards for the diagnosis and treatment of respiratory tract infections is essential. 4. Systematic training in effective and judicious use of antimicrobial therapy seems necessary for every physician.

Key words: respiratory tract infections, antimicrobial therapy, general practitioner (GP).

Fam Med Prim Care Rev 2016; 18(3): 332-335

\section{Background}

Respiratory tract infections are among the most common reasons for patients to contact primary health care $(\mathrm{PHC})[1$, 2]. Despite the viral etiology of respiratory tract infections, antimicrobial therapy is commonly used $[3,4]$. Respiratory tract infections are the most frequent cause for which $\mathrm{PHC}$ doctors prescribe antibiotics. The excessive use of antibiotics has negative economic and social effects. Antibiotic resistance caused by the inappropriate use of antibiotics is an important issue, not only in Poland, but worldwide [4, 5].

Information on the reasons behind the excessive use of antibiotics, as well as the implementation of the proper mechanisms and recommendations in line with evidencebased medicine (EBM), seems crucial for society as a whole.

\section{Objectives}

The study aimed to establish the incidence of respiratory tract infection and to analyze the structure of antibiotic prescription in primary health care $(\mathrm{PHC})$.

\section{Material and methods}

The medical records of 500 adult patients, treated for respiratory tract infection from 2 January to 14 March 2014, in a chosen PHC facility in Pomeranian province, were examined. The diagnoses were made according to the International Statistical Classification of Diseases and Related Health Problems (ICD-10). The retrospective analysis of the medical records included symptoms, disease duration, and any antibiotics prescribed. The treatment was conducted by 5 specialists in family medicine and 2 doctors with a secondary specialization in internal medicine. The data refer to $320(64 \%)$ women and $180(36 \%)$ men. The age median was 51 years (range: 18-100).

The analysis was performed within the framework of the ST-72 statutory research of the Medical University of Gdańsk (MUG). The consent of the Independent Bioethics Commission for Scientific Research Affairs at the MUG was obtained.

\section{Statistical analysis}

Statistical analysis was carried out using Statistica 10 $\mathrm{PL}$. The normality of the age variable distribution was established using the Shapiro-Wilk test. The qualitative variables were presented as number and percentage. As the age variable distribution deviates from normal, it was presented by means of the median with the minimum and maximum value. 


\section{Results}

The results of the analysis are presented in the following tables and figures.

As Table 1 shows, acute upper respiratory infections of multiple and unspecified sites was the most frequently diagnosed disease $(57.2 \%)$, acute bronchitis was second most frequently diagnosed $(10.2 \%)$, and 2 patients $(0.4 \%)$ were diagnosed with influenza. $67.2 \%$ of the 500 patients with respiratory tract infections were prescribed antibiotics (as shown in Figure 1).

The frequencies of use of particular classes of antibiotics are shown in Figure 2.

The frequency with which antibiotics were prescribed is shown in Table 2 by diagnosis type.

\begin{tabular}{|l|l|l|}
\hline \multicolumn{2}{|l|}{ Table 1. The incidence of diseases J00-J22 in the group of 500 PHC patients } \\
\hline ICD-10 & ICD-10 disease name & $n(\%)$ \\
\hline J00 & acute nasopharyngitis (common cold) & $85(17)$ \\
\hline J01 & acute sinusitis & $8(1.6)$ \\
\hline J02 & acute pharyngitis & $32(6.4)$ \\
\hline J03 & acute tonsillitis & $19(3.8)$ \\
\hline J04 & acute laryngitis and tracheitis & $4(0.8)$ \\
\hline J06 & acute upper respiratory infections of multiple and unspecified sites & $286(57.2)$ \\
\hline J11 & influenza, virus not identified & $2(0.4)$ \\
\hline J18 & pneumonia, organism unspecified & $9(1.8)$ \\
\hline J20 & acute bronchitis & $51(10.2)$ \\
\hline J22 & unspecified acute lower respiratory infection & $4(0.8)$ \\
\hline
\end{tabular}

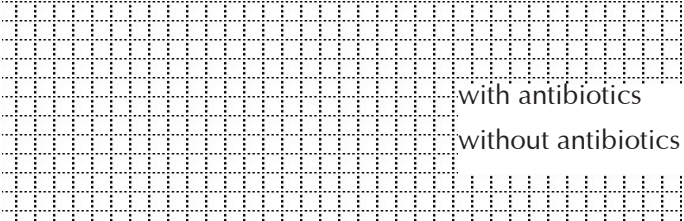

Figure 1. Frequency of antibiotic use in the group of 500 patients with respiratory tract infections

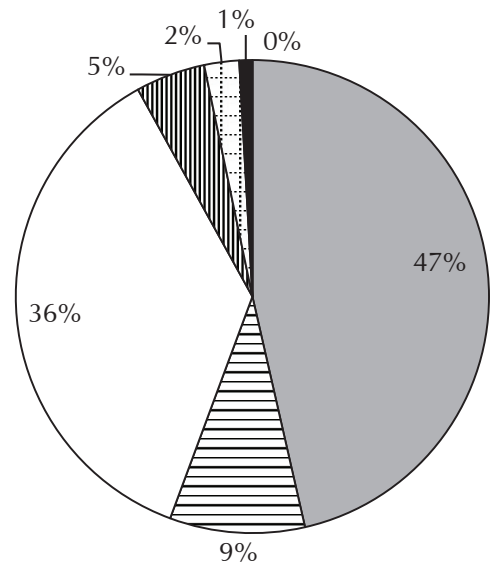

口penicillins

口.cephalosporins I, II 口 macrolides m fluoroquinolones $\square$ lincosamides - tetracyclines 口 co-trimoxazole

Figure 2. Types of antibiotics used in $500 \mathrm{PHC}$ patients

\begin{tabular}{|l|l|l|l|l|l|l|l|}
\hline \multicolumn{7}{|l}{ Table 2. Frequency of antibiotic prescription by disease diagnosis (J00-J22) in 500 PHC patients } \\
\hline $\begin{array}{l}\text { ICD-10 } \\
\text { diagnosis }\end{array}$ & $\begin{array}{l}\text { No antibiotics } \\
n(\%)\end{array}$ & $\begin{array}{l}\text { Penicillins } \\
n(\%)\end{array}$ & $\begin{array}{l}\text { Cephalospo- } \\
\text { rins I, II } \\
n(\%)\end{array}$ & $\begin{array}{l}\text { Macrolides } \\
n(\%)\end{array}$ & $\begin{array}{l}\text { Fluoroquino- } \\
\text { lones } \\
n(\%)\end{array}$ & $\begin{array}{l}\text { Lincosamides } \\
n(\%)\end{array}$ & $\begin{array}{l}\text { Tetracyclines } \\
n(\%)\end{array}$ \\
\hline $\mathrm{J} 00$ & $80(94.12)$ & $3(3.53)$ & $0(0)$ & $2(2.35)$ & $0(0)$ & $0(0)$ & $0(0)$ \\
\hline $\mathrm{J} 01$ & $1(12.5)$ & $4(50)$ & $0(0)$ & $2(25)$ & $0(0)$ & $1(12.5)$ & $0(0)$ \\
\hline $\mathrm{J} 02$ & $6(18.75)$ & $11(34.38)$ & $2(6.25)$ & $9(28.13)$ & $0(0)$ & $3(9.38)$ & $1(3.13)$ \\
\hline $\mathrm{J} 03$ & $3(15.79)$ & $8(42.11)$ & $4(21.05)$ & $0(0)$ & $0(0)$ & $4(21.05)$ & $0(0)$ \\
\hline $\mathrm{J} 04$ & $0(0)$ & $2(50)$ & $0(0)$ & $2(50)$ & $0(0)$ & $0(0)$ & $0(0)$ \\
\hline $\mathrm{J} 06$ & $62(21.68)$ & $113(39.50)$ & $6(2.10)$ & $92(32.16)$ & $11(3.85)$ & $0(0)$ & $2(0.7)$ \\
\hline $\mathrm{J} 11$ & $1(50)$ & $0(0)$ & $0(0)$ & $1(50)$ & $0(0)$ & $0(0)$ & $0(0)$ \\
\hline $\mathrm{J} 18$ & $3(33.3)$ & $2(22.2)$ & $2(22.2)$ & $1(11.1)$ & $1(11.1)$ & $0(0)$ & $0(0)$ \\
\hline $\mathrm{J} 20$ & $6(11.76)$ & $12(23.53)$ & $16(31.37)$ & $13(25.49)$ & $4(7.84)$ & $0(0)$ & $0(0)$ \\
\hline $\mathrm{J} 22$ & $2(50)$ & $1(25)$ & $1(25)$ & $0(0)$ & $0(0)$ & $0(0)$ & $0(0)$ \\
\hline
\end{tabular}




\section{Discussion}

The too-frequent use of antibiotics and the consequent growth in the antibiotic resistance of pathogens, poses an epidemiological threat worldwide [5]. According to various authors, antibiotics are prescribed in up to $70 \%$ of diagnosed respiratory infections $[6,7]$. The available studies conducted in Poland show that there has been a significant variation in the use of this medication. Up to $82 \%$ of patients with acute respiratory infections were administered an antibiotic during their first visit to doctors in the Lublin region; in Białystok, $61.1 \%$ of patients received similar treatment [9].

Our analysis of 500 patients at a PHC facility in Pomeranian province showed that $67.2 \%$ of the patients were treated with antibiotics. Our study also indicated that more frequent use of antibiotics occurred in respiratory tract infections in the research carried out by doctors working with the MUG Department of Family Medicine, who are regularly trained under the SEKSTANS Constant Education program. $60 \%$ of a group of a few hundred patients admitted with a diagnosis of respiratory infections were treated symptomatically. Symptomatic treatment was given to $57.8 \%$ of patients in 2012/2013 season and to $63.4 \%$ in 2013/2014 [10, 11]. The doctors were required to use the Centor scale, as well as other methods of supporting diagnosis and therapy.

On conducting the Happy Audit international program, it was discovered that doctors who use questionnaires, scales (such as the Centor scale), rapid tests for streptococci, and CRP tests clearly tended to prescribe antibiotics far less frequently [12]. Muszyńska et al. [13] obtained similar results when they examined the usefulness of CRP rapid tests in the everyday work of family doctors.

The differences in these results may be caused by a number of factors. The large number of patients seen by family doctors and the time pressure associated with this may be one reason. It was also noticed that inappropriate use of antibiotics may have arisen from patients' beliefs that they know the appropriate treatment and their consequent expectation of being prescribed antibiotics $[14,15]$. The inability to quickly verify the etiology of the infection may also have been an important reason for antimicrobial therapy.

Studies show that prescribing antibiotics when demanded by patients does not result in a smaller number of visits [16]. The appropriate education of patients, and spending time on fully communicating and explaining the doctor's doubts to them, are equally important parts of the patients' treatment and satisfaction [17].
Well-trained doctors who have adequate skills and supportive diagnostic methods tend to feel more confident about their diagnosis [18]. Systematic workshops on clinical communication and assertiveness seem useful as well.

Despite the regularly updated recommendations of the National Program for the Conversation of Antibiotics on the rational use of antibiotics, antimicrobial therapy is extremely prevalent in Poland. A broader information campaign among doctors and patients is needed, as is a greater emphasis on doctors complying with the guidelines for rational antimicrobial therapy consistent with EBM principles [3, 19, 20].

It is also worth noticing that amoxicillin and amoxicillin with clavulanic acid were the only penicillins prescribed (46.43\% of the prescribed antibiotics). Not even phenoxymethyl penicillin was prescribed, although it is recommended as a first-line drug in bacterial pharyngitis, tonsillitis and streptococcal angina [20]. Chlabicz and Pytel-Krolczuk obtained similar results in their research on the use of penicillin [19]. The relatively large percentage of macrolides (36.31\%) prescribed by primary care physicians follows a trend observed in many countries [21], including Poland [11]. It should be pointed out that it may be difficult to verify the etiology of atypical pathogen infections under PHC conditions.

The essential value of this paper lies in the fact that it illustrates the procedure applied in respiratory tract infections under real conditions of an outpatient medical facility. However, the fact that the sample was limited to a single PHC center means that the results cannot be generalized. No in-depth statistical analysis of the relationship between the variables was carried out, due to the limited scope of the work. Further investigations will be conducted on a larger group of patients and will appear in subsequent publications. The comparative nature of our results and the results obtained by the group working within the program recommending Happy Audit procedures seem worth continuing.

\section{Conclusions}

1. Acute upper respiratory tract infection with multiple or unspecified sites was diagnosed most frequently.

2. Despite increasing awareness of the risks involved in the excessive use of antibiotics, antimicrobials were often prescribed. Semisynthetic penicillins and macrolides were used most often.

3. Implementation of uniform national standards for the diagnosis and treatment of respiratory tract infections is essential.

4. Systematic training in effective and judicious use of antimicrobial therapy seems necessary for every physician.

Source of funding: This work was funded by the authors' resources. Conflict of interest: The authors declare no conflict of interests.

\section{References}

1. Hryniewicz W. Alexander Project - 5 years in Poland. Pol Merkuriusz Lek 2003; 14(79): 5-8.

2. Panasiuk $L$, Lukas W, Paprzycki $P$, et al. Antibiotics in the treatment of upper respiratory tract infections in Poland. Is there any improvement? J Clin Pharm Ther 2010; 35(6): 665-669, doi: 10.1111/j.1365-2710.2009.01136.x.

3. Dzierżanowska D. Antybiotykoterapia praktyczna. Bielsko-Biała: Wydawnictwo alfa-medica press; 2009.

4. Goossens H. Outpatient antibiotic use in Europe and association with resistance: a cross-national database study. Lancet 2005; 365(9459): 579-587.

5. Bronzwaer SL, Cars O, Buchholz U, et al. The relationship between antimicrobial use and antimicrobial resistance in Europe. Emerg Infect Dis 2002; 8(3): 278-282.

6. Straand J, Rokstad KS, Sandvik H. Prescribing systemic antibiotics in general practice. A report from the Mřre \& Romsdal prescription study. Scand J Prim Health Care 1998; 16(2): 121-127.

7. McCaig LF, Hughes JM. Trends in antimicrobial drug prescribing among office-based physicians in the United States. JAMA 1995; 273(3): 214-219.

8. Panasiuk L, Lukas W, Paprzycki P. Empirical first-line antibioticotherapy in adult rural patients with acute respiratory tract infections. Ann Agric Environ Med 2007; 14(2): 305-311.

9. Chlabicz S, Ołtarzewska AM, Pytel-Krolczuk B. Respiratory tract infections: diagnosis and use of antibiotics by family physicians in north-eastern Poland. Int J Antimicrob Agents 2004; 23(5): 446-450. 
10. Gutknecht P, Trzeciak BG, Winiarski T, et al. Diagnostyka i leczenie zakażeń układu oddechowego u pacjentów wybranych praktyk lekarzy rodzinnych na terenie Gdańska. Fam Med Prim Care Rev 2013; 15(3): 320-322.

11. Gutknecht P, Winiarski T, Trzeciak BG, et al. Zakażenia dróg oddechowych w praktyce lekarza rodzinnego: zgłaszane objawy, stosowane leczenie : obserwacja dwuletnia. Fam Med Prim Care Rev 2014; 16(3): 228-230.

12. Godycki-Cwirko M, Jochen W, Cals L, et al. Public beliefs on antibiotics and symptoms of respiratory tract infections among rural and urban population in Poland: a questionnaire study. PLOS ONE 2014; doi: http://dx.doi.org/10.1371/journal.pone.0109248.

13. Scott JG, Cohen D, DiCicco-Bloom B, et al. Antibiotic use in acute respiratory infections and the ways patients pressure physicians for a prescription. J Fam Pract 2001; 50(10): 853-858.

14. Li J, De A, Ketchum K, et al. Antimicrobial prescribing for upper respiratory infections and its effect on return visits. Fam Med 2009; 41(3): 182-187.

15. Cals JW. Effect of point of care testing for C-reactive protein and training in communication skills on antibiotic use in lower respiratory tract infections: cluster randomised trial. BMJ 2009; 338(NUMER): b1374.

16. Llor C, Bjerrum L, Munckk A, et al. Access to point-of-care tests reduces the prescription of antibiotics among antibioticrequesting subjects with respiratory tract infections. Respir Care 2014; 59(12): 1918-1923, doi: 10.4187/respcare.03275.

17. Strumiło J, Chlabicz S, Ovhed I, et al. Management of respiratory tract infections in primary care in Poland - results of the happy audit 2 project. Prz Epidemiol 2014; 68(1): 33-38, 121-125.

18. Muszyńska A, Steciwko A, Siebert J, et al. Przydatność szybkich testów CRP (NycoCard II CRP) w codziennej pracy lekarza rodzinnego w aspekcie racjonalizacji wskazań do antybiotykoterapii w ostrych infekcjach. Fam Med Prim Care Rev 2007; 9(4): 998-1006.

19. Chlabicz S, Pytel-Krolczuk B. Antibiotic treatment for respiratory tract infections in Polish primary care facilities: is it time to change national guidelines or doctor prescribing behaviour? J Eval Clin Pract 2008; 14(3): 470-472, doi: 10.1111/j.13652753.2007.00865.x.

20. Dzierżanowska D, Dzierżanowska-Fangrat K. Przewodnik antybiotykoterapii. Bielsko-Biała: Wydawnictwo alfa-medica press; 2016.

21. Hinnerskov M, Therkildsen JM, Cordoba G, et al. Macrolide overuse for treatment of respiratory tract infections in general practice. Dan Med Bull 2011; 58(11): A4356.

Address for correspondence:

Małgorzata Pietrzykowska, MD

Katedra Medycyny Rodzinnej GUM

ul. Dębinki 2

80-211 Gdańsk

Polska

Tel.: +48 58 349-15-75

E-mail: malpiet@gumed.edu.pl

Received: 01.04.2016

Revised: 08.05.2016

Accepted: 20.05.2016 